\title{
Potential of Livestock Generated Biomass: Untapped Energy Source in India
}

\author{
Gagandeep Kaur ${ }^{1, *}$ (D), Yadwinder Singh Brar ${ }^{1}$ and D.P. Kothari ${ }^{2}$ \\ I. K. Gujral Punjab Technical University, 144603 Punjab, India; braryadwinder@yahoo.co.in \\ 2 Ex-Vice Chancellor, VIT, Vellore, 632014 Tamil Nadu, India; dpkvits@gmail.com \\ * Correspondence: simicgagan@gmail.com or gaganee@ptu.ac.in; Tel.: +91-947-809-8118
}

Received: 9 May 2017; Accepted: 20 June 2017; Published: 25 June 2017

\begin{abstract}
Modern economies run on the backbone of electricity as one of major factors behind industrial development. India is endowed with plenty of natural resources and the majority of electricity within the country is generated from thermal and hydro-electric plants. A few nuclear plants assist in meeting the national requirements for electricity but still many rural areas remain uncovered. As India is primarily a rural agrarian economy, providing electricity to the remote, undeveloped regions of the country remains a top priority of the government. A vital, untapped source is livestock generated biomass which to some extent has been utilized to generate electricity in small scale biogas based plants under the government's thrust on rural development. This study is a preliminary attempt to correlate developments in this arena in the Asian region, as well as the developed world, to explore the possibilities of harnessing this resource in a better manner. The current potential of 2600 million tons of livestock dung generated per year, capable of yielding 263,702 million $\mathrm{m}^{3}$ of biogas is exploited. Our estimates suggest that if this resource is utilized judiciously, it possesses the potential of generating $477 \mathrm{TWh}$ (Terawatt hour) of electrical energy per annum.
\end{abstract}

Keywords: biogas; cows dung; electrical energy; India; livestock

\section{Introduction}

Indiscriminate consumption of fossil fuels to meet energy demand for the burgeoning human population world-wide, especially in high population density nations, is primarily responsible for three quarters of the total world figures for greenhouse gas (GHG) generation [1,2]. The role of GHG as the main contributor to global warming poses a challenge to all life forms on the planet and it is now recognized as a distinct obstacle in the sustainability and living conditions of future generations $[3,4]$. The high growth rate of the human population and tendencies towards urbanization during the last few decades have raised energy demand which is likely to grow by 25\% (700 Quadrillion British Thermal Units) of the present figure, by the year 2040 [5]. In order to fulfill this expected rise in energy demand, alternative sources need to be identified and tapped due to the now recognized likelihood of the exhaustion of fossil fuels. It therefore becomes essential that the best available source of green energy be identified, with a premise that it should be sustainable, should possess the capability of being replenished consistently, and the process should be both natural and bio-friendly [6,7]. If the focus is shifted to a regional level in the Asia-Pacific region, the Indian sub-continent is a likely candidate to explore such possibilities due to the qualifying criteria of being a land mass of varied flora and fauna which can generate enough biomass for the investigation being conducted. India is the world's seventh largest land-mass spreading over 328 million hectares and is expected to become the most populous nation of the world by the year 2025 [5,8]. Politically, India is divided into 35 provinces and union-territories (UTs). India has six main climatic sub-types, ranging from deserts in the west, 
glaciers in the north, tropical humid climate in the southwest, and has a huge coastline because the sub-continent is a geographic peninsular. India's climate is influenced by its unique geographical and geological features conducive to varied life forms. These features facilitate the existence of a wide variety of vegetable and animal life forms which contribute to, as well as generate, huge biomass, which can be tapped as potential source for energy. The last two decades have witnessed an economic surge in India and the Gross Domestic Product (GDP) is expected to rise three-fold by the year 2040 [5]. With considerable demand for energy in rural and urban Indian communities, there is a discernible trend of a gradual shift from non-renewable to renewable energy sources, the latter being identifiable as ideal and a better alternative for guaranteed energy access to consumers $[9,10]$. Agriculture, forest, and livestock-based bio waste/ byproducts are called biomass or bio-residues, and are available in plenty in India [11]. Biomass-based energy generation is popular in rural areas due to infrastructural constraints in delivery of conventional energy fuels [12]. Bio energy has merit as it is renewable and extractable from organic matter by utilizing simple and economical techniques and processes of anaerobic digestion (AD). Such techniques possess the ability of yielding sufficient amounts of practically usable biogas. [13]. Biogas is an already identified eco-friendly energy source with main components being methane $(60 \%-70 \%)$ and carbon-dioxide $(35 \%-40 \%)[14,15]$. Another innovative technique developed in recent years to utilize available biomass is development of the Microbial Fuel Cell (MFC) [16]. MFCs are currently under intensive research and thus far researchers have been able to obtain a maximum power density of $3600 \mathrm{MW} / \mathrm{m}^{2}$ with glucose fed as substrate using common available raw biomass components [17]. A typical MFC is a bio-reactor which converts chemical energy in bio-convertible substrates directly into electricity by action of specific microorganisms which facilitate the conversion of substrate directly into electrons [18]. It is not that biomass available in India is so far being wasted. Since ancient times, biomass generated by domesticated livestock has been the primary source of domestic energy in India. It meets the kitchen energy requirements of most rural, and approximately one-half of urban house-holds [11]. Livestock dung, comprising of excreta and urine still finds usage as a vital, renewable, and sustainable precursor for producing bio-fertilizer (farm yard manure), biogas, and a unique product specific to South Asia i.e., cow-dung cakes, caked and dried dairy animal feces which are used for burning as fuel in traditional, earthen ovens [19]. To promote usage of biomass, efficient energy conversion technologies have been developed by Government of India and many biogas plants are successfully running in progressive rural sectors. Unfortunately, despite exponential economic growth, energy production in India remains deficient, as approximately one fourth of the country's population, and $44 \%$ of the rural population, do not have access to grid-based electricity. It is pertinent to mention here that per capita electricity consumption in India is just $814 \mathrm{kWh}$, which is moderate $(24 \%)$ when compared with the global average consumption $[20,21]$. Annual energy demand rose from 830,594 MU (million units) to 1,142,092 MU as per 2009 assessment of the energy sector. Subsequently, although electricity generation was hiked from 770 MUs to 1160 MUs, deficiency persists in the rural sector. Current renewable source energy generation stands at just $15 \%$ of total energy generated from all known sources. Of this, biomass-based power generation stands at just $2 \%$, despite it being capable of contributing more [22]. India thus has ample room to enhance energy generation by utilizing renewable energy sources, especially biomass-based bio energy. India's livestock population is one of the largest in world with current total population standing at 512.05 million [23]. This sector occupies second rank after agriculture in energizing and boosting rural economic trends. Contribution of livestock to GDP is $4.11 \%$ at current price index [24,25]. In the majority of Indian provinces, two-thirds of the population is directly or indirectly involved in dairy and poultry farming. Livestock dung therefore plays a vital role in rural economy and its judicious and proper utilization by introducing modern processing technologies may contribute in a significant manner to enhance rural incomes by utilizing this huge biomass for power generation $[25,26]$. Probing livestock excreta as a likely potential green energy source and therefore needs in-depth analysis. If this potential source of energy can be harnessed in an economical manner, it is likely to contribute in 
a significant manner to reducing stress on the conventional coal and hydro-electric-based national electric grid.

\section{Indian Scenario}

\subsection{Energy Scenario in India}

Despite world-wide recession, the Indian economy is growing at a tremendous rate compared to rest of the world. Ironically, the margin of economic growth in rural and urban regions is separated by a great chasm [27]. Further, current estimates suggest that around $25 \%$ of the national population, and $44 \%$ of the rural population, are bereft of access to grid-based electricity distribution, the primary reason for this gap [28]. All regions continue to experience shortage in electrical energy year round and peak demand rises with each passing year. Surplus power in some provinces is generally sold to deficit provinces but the national situation remains dismal. However, over the last few years India has been able to squeeze the gap to a certain extent [29]. Table 1 and Figure 1a summarize the updated overall national energy scenario. Despite confronting consistent deficit, installed energy generation capacity in India has improved from 145,755 MW in the year 2006 to 319,606 MW in year 2017, which can be considered a fair level of improvement [30]. Since 2009, energy generation was enhanced from $771 \mathrm{BU}$ to current level of $1160 \mathrm{BU}$, which is significant [22]. Figure $1 \mathrm{~b}$ illustrates the year to year growth rate of installed energy generation capacity. In 2017, from the total installed energy generation capacity share of provinces, central, and private sectors stood at $35 \%, 25 \%$, and $42 \%$ respectively. Presently, energy is generated primarily from thermal power units [(68\%) $(218,330 \mathrm{MW})]$ by utilizing conventional sources like coal, gas, and oil as fuel. The remaining requirement is met from hydroelectric $[(14 \%)$ $(44,478 \mathrm{MW})]$, nuclear [(2\%) $(6780 \mathrm{MW})]$, and renewable energy source [(16\%) $(50,018 \mathrm{MW})]$ based power plants [30]. For sustainable development, efforts to promote bio energy from available biomass resources have been ongoing [31]. However, the full potential has not been exploited for the generation of electricity from biomass. It still stands at a poor $2 \%$ of all potential alongside other exploitable renewable energy resources [32]. Current renewable energy source utilization stands at $16 \%$ of the total energy produced, of which $83.54 \%$ is from solar power, $11.46 \%$ from wind power, $2.2 \%$ from small hydro-electric power plants, $1.96 \%$ from biomass, and $0.56 \%$ from bagasse burning [22]. Current estimates suggest that it is possible to generate approximately 17,538 MW of power from presently available biomass. The Ministry of New and Renewable Energy (MNRE) of India actively promotes biomass-based power plants. Such plants are primarily located in rural areas where abundant biomass exists. As per available data, India has 5940 MW biomass based plants, out of which 4946 MW are grid connected and $994 \mathrm{MW}$ are off-grid [33].

Table 1. Energy and peak demand scenario in India.

\begin{tabular}{ccccccc}
\hline Year & $\begin{array}{c}\text { Energy } \\
\text { Requirements } \\
\text { (MUs) }\end{array}$ & $\begin{array}{c}\text { Energy } \\
\text { Achieved } \\
\text { (MUs) }\end{array}$ & $\begin{array}{c}\text { Energy } \\
\text { Surplus(+)/ } \\
\text { Deficit(-) } \\
\mathbf{( \% )}\end{array}$ & $\begin{array}{c}\text { Peak Energy } \\
\text { Demand } \\
\text { (MW) }\end{array}$ & $\begin{array}{c}\text { Peak Energy } \\
\text { Achieved } \\
\text { (MW) }\end{array}$ & $\begin{array}{c}\text { Peak Energy } \\
\text { Surplus(+)/ } \\
\text { Deficit(-) (\%) }\end{array}$ \\
\hline $2009-2010$ & 830,594 & 746,644 & -10.1 & 119,166 & 104,009 & -12.7 \\
$2010-2011$ & 861,591 & 788,355 & -8.5 & 122,287 & 110,256 & -9.8 \\
$2011-2012$ & 937,199 & 857,886 & -8.5 & 130,006 & 116,191 & -10.6 \\
$2012-2013$ & 995,557 & 908,652 & -8.7 & 135,453 & 123,294 & -9.0 \\
$2013-2014$ & $1,002,257$ & 959,829 & -4.2 & 135,918 & 129,815 & -4.5 \\
$2014-2015$ & $1,068,923$ & $1,030,785$ & -3.6 & 148,166 & 141,160 & -4.7 \\
$2015-2016$ & $1,114,408$ & $1,090,850$ & -2.1 & 153,366 & 148,463 & -3.2 \\
$2016-2017$ & $1,142,092$ & $1,134,633$ & -0.7 & 159,542 & 156,934 & -1.6 \\
\hline
\end{tabular}




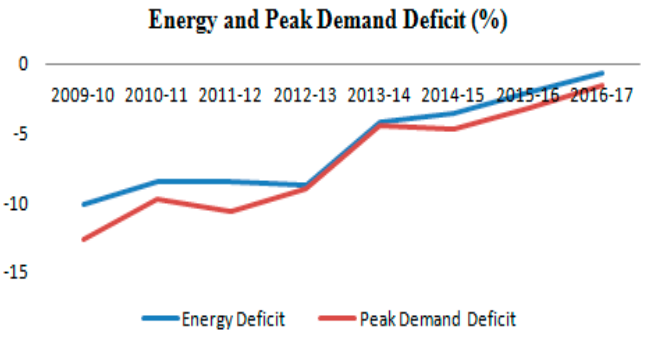

(a)

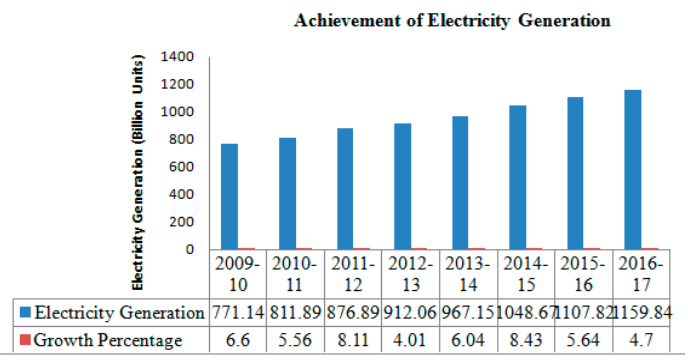

(b)

Figure 1. (a) Energy and peak demand deficit in India; (b) Achievement of electricity generation in India.

Off-grid capacity contributes $652 \mathrm{MW}$ from captive power plants, $18 \mathrm{MW}$ from biomass gasifier systems, of which $164 \mathrm{MW}$ equivalent biomass gasifier systems are deployed for thermal applications. Leading provinces for biomass projects are Maharashtra, Uttar Pradesh, Karnataka, Tamil Nadu, Andhra Pradesh, Chhattisgarh, and Punjab [33]. Provincial figures of energy generation utilizing biomass are depicted in Figure 2a.

\subsection{Livestock Scenario}

The livestock sector contributes significantly to generating employment in rural India, especially for landless people and marginal farmers, providing nutritious food to millions of people. Livestock practice has been a lifesaving asset during catastrophes like floods and drought. According to national survey, about 16.44 million people are directly or indirectly involved in the livestock sector [34]. According to the 19th Livestock census report, national livestock population stands at 512 million, comprising mainly of cows, buffaloes, sheep, goats, pigs, and other species including poultry. Figure $2 \mathrm{~b}$ presents the percentage population share of these species in total livestock. Consistent increase in herd sizes over the years has led to generation of enormous livestock waste. This waste not only causes air pollution, but contributes to atmospheric and ground water contamination as well. Generation of obnoxious and potent gases, like methane and nitrous oxide, contributes to environmental pollution leading to serious public health issues. Scientific measures to stop this environmental degradation are therefore absolutely essential [35-37]. Safe disposal of such gigantic proportions of livestock waste otherwise rich in organic matter poses a serious hurdle to development [38]. Indian traditional lifestyles have a very efficient means of disposal of dung in which dung is collected from individual houses in a large village heap at a strategic location in the village. Bacterial degradation results in the heap turning into compost which is later bought by farmers to fertilize their fields. Some portion of the cow-dung is shaped into cakes used as fuel in earthen ovens (Figure 2c).

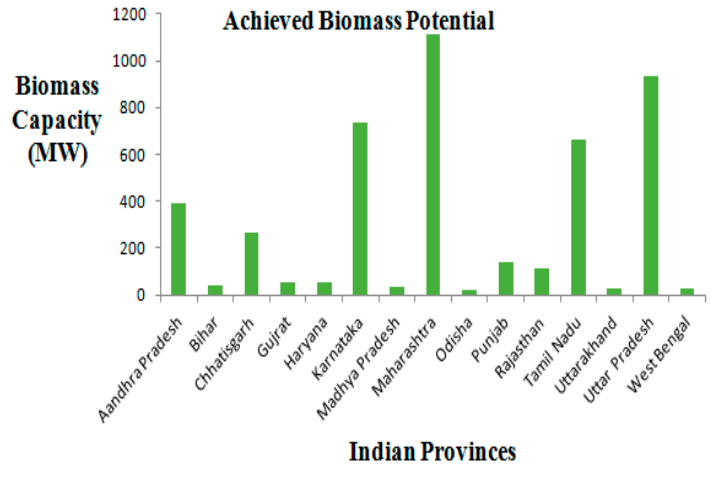

(a)

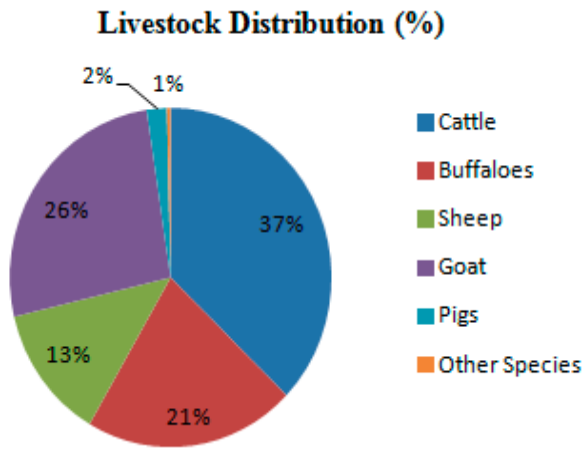

(b)

Figure 2. Cont. 
Step 1: Fresh Cow-Dung from farm

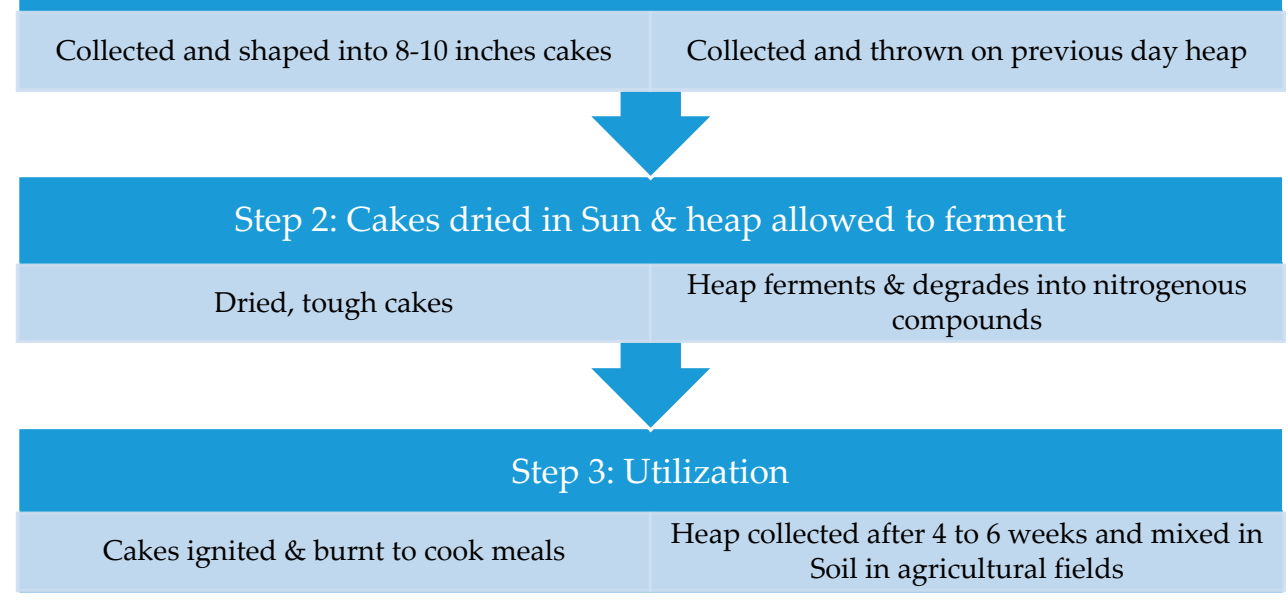

(c)

Figure 2. (a) Province-wise commulative achieved biomass and cogeneration power; (b) Species-wise livestock distribution in Indain provinces; (c) Flow-chart showing traditional use of cow-dung as kitchen fuel and manure.

Dried cow-dung (calorific value $14 \mathrm{MJ} / \mathrm{kg}$ ) has been used to generate power in other countries as it yields the same amount of combustible energy as dried firewood (calorific value 16-20 MJ/kg) [39]. 150 million tons of cow-dung is presently being used in the world as fuel and $40 \%$ of this total usage occurs in India. The most widely used practices in ascending order for dung management are composting, dumping in landfills, disposal via common effluent treatment plant, or by dumping in open waste spaces. Animal dung and waste water collectively generate waste on the order of 3 million to 6000 million tons per day. It is estimated that just $9 \%$ of the total biomass generated by livestock is utilized for biogas recovery $[40,41]$. As a remedial measure, the latest cost-effective and eco-friendly energy techniques for utilization of livestock waste biomass to generate energy are needed.

\subsection{Energy Conversion Techniques}

Among all energy conversion techniques, the most efficient and appropriate technique for dung conversion to electrical energy is anaerobic digestion. Anaerobic digestion (AD) converts energy stored in dung into biogas, which can be utilized to generate electrical energy. Anaerobic digestion is degradation of organic material by microbial action in absence of air, transforming it into biogas, a mixture of methane, carbon dioxide, and some other trace gases. In this system dung is collected and mixed with an optimum amount of water. Microbes are already present or special cultures can be added to enhance microbial degradation. Pre-treatments like screening, grit removal, mixing, and flow equalization enhances the yield of recoverable biogas which is later utilized in a combustion engine to generate electricity. Generated biogas primarily consists of methane $(50 \%-75 \%)$, carbon dioxide $(25 \%-50 \%)$, and minute quantities of other gases like hydrogen-sulfide $\left(\mathrm{H}_{2} \mathrm{~S}\right)$ and ammonia $\left(\mathrm{NH}_{4}\right)$ [42]. Biogas generated in this manner has 'High Heating Value' (HHV) ranging from $16 \mathrm{MJ} / \mathrm{m}^{3}$ to $25 \mathrm{MJ} / \mathrm{m}^{3}$. The electrical energy content of typical biogas is $5-7 \mathrm{kWh} / \mathrm{m}^{3}$ of biogas produced if a standard biogas yield of $0.04 \mathrm{~m}^{3} / \mathrm{kg}$ is recoverable [43,44]. Methane gas generated by this methodology has traditionally been used as fuel for lighting and other electricity-dependent machines [45]. Current research reveals that $1 \mathrm{~kg}$ of cow-dung mixed with an equal quantity of water, and with a total hydration retention time of 55-60 days, when maintained at ambient temperature of $24-26^{\circ} \mathrm{C}$ and yields $35-40$ liters of biogas [45]. As compared to other renewable energy generation raw materials, livestock dung is a better alternative as it is economical, requires less capital investment, and has the least per unit cost of 
production [46,47]. Researchers are consistently working for other alternative means for generation of sustainable energy from livestock dung and MFC is presumed to be the front runner as an alternative to just using the methane gas to fuel generators. A MFC is an assembly which can capture the electrons generated by the metabolism of microorganisms and hold the charge to maintain a stable, continuous source of energy [48]. Special strains of microorganisms in dung promote conversion of substrate into electrons in a better manner [49]. Cow-dung contains myriad organic carbon sources which are subject to oxidative processes by action of microorganisms to yield electric energy [50]. The maximum achievable MFC voltage is theoretically on the order of 1.1 Volt $[48,49,51]$. This has raised an immense curiosity in cows dung as a probable contender for sustainable energy generation. At this time, bio-energy is being looked at as a prospective alternative to fulfill the requirements of an ideal renewable energy source of the future. The livestock, dairy, and poultry industries generate enormous amounts of waste and the annual amount can be staggering even for a small-scale farm. It is crystal clear that in the Indian scenario, inexhaustible potential for conversion of livestock biomass waste to energy exists, and possesses the likelihood of contributing significantly to the total energy demand [32]. An attempt, therefore, needs to be made to explore the available livestock waste and its potential for conversion to biogas for generation of electricity by all means possible with currently available and feasible technology. Any constraints to this effect need to be identified and thoroughly investigated before a venture in this direction can be made. In India, many agencies and private commercial ventures practicing conversion of a variety of biomass resources to energy, such as bagasse utilization in the sugar industry, to generate electricity exist. However, their contribution is miniscule if compared to the requirement [32]. A comprehensive region-wise study needs to be conducted to ascertain the potential of biogas production by utilizing livestock dung as the primary source so that essential guidelines and recommendations for relevant biomass management technology can be formulated. The outcome of this exercise may serve as a guiding force for the application of this venture as a likely, still untapped source of energy which holds promise as a bio-friendly and sustainable means to the envisaged end.

\section{Materials and Methods}

To evaluate the extent and potential of effectively utilizing biogas as a source of power generation, the amount of livestock and poultry waste generated in the country was obtained from figures published by the Ministry of Agriculture and Farmer Welfare, India [23]. Out of 35 provinces and union territories (UTs) of India, 18 major provinces had significant amounts of livestock waste generated as per latest figures, while 17 provinces/UTs (labeled "Other Provinces" in above figures) contribution was minuscule. Data from the major livestock waste-generating provinces will therefore only be considered. The statistical data includes population of livestock assets comprising mainly cows, buffaloes, sheep, goats, pigs, and poultry. Species like horses, ponies, camel, yak, and mithun were excluded from this study due to their being less than $1 \%$ of the total livestock population in India [23]. By considering the average body weight of each participating animal species, annual livestock dung and biogas generation were estimated. Significant parameters like total solids and animal dung availability were considered as they had implications and inter-dependence on biogas generation potential. Relevant calculations are depicted in following sub sections:

\subsection{Gross Estimate of Amount of Livestock Waste Generated in India}

To determine the livestock and poultry waste generated in India, state-wise statistical livestock data published by DADF, Ministry of Agriculture was accessed (Figure 3). In terms of population, India's current livestock population figures include 191 million cows, 109 million buffaloes, 65 million sheep, 135 million goats, 10 million pigs, and about 729 million poultry. The quantity of livestock dung generated invariably depends on multiple factors: such as type of animal, animal husbandry practices in operation, quantity, and ingredients of feed, whether confined or range animals, and general features like weight and size of typical breeds of each animal species $[52,53]$. To calculate the average amount 
of dung produced by livestock, enlisted species were categorized by size as large animals (cows and buffaloes), small animals (sheep and goats), pigs, or poultry (broiler, layer, and other). Past research pinpoints that the average production of dung ranged between $10-20 \mathrm{~kg} /$ day ( 5 to $6 \%$ of body weight), $2 \mathrm{~kg} /$ day ( 4 to $5 \%$ of body weight), $4 \mathrm{~kg} /$ day ( 5 to $7 \%$ of body weight) and $0.1 \mathrm{~kg} /$ day (3 to $4 \%$ of body weight) for cows and buffalo, sheep and goat, pig and poultry respectively in Asia [53,54]. In the present study, the quantity of dung generated by enlisted species was calculated by assuming livestock weight as 250, 40, 80, and $1.5 \mathrm{~kg}$ for Bovine, Caprine, Porcine, and avian species respectively, measured in kilograms for the average domesticated breeds in India. Accordingly, average standard values of $22.5 \mathrm{~kg} /$ day ( $9 \%$ body weights), $1.6 \mathrm{~kg} /$ day (based on $4 \%$ of body weight), $2.7 \mathrm{~kg} /$ day (based on $9 \%$ of body weight), and $0.045 \mathrm{~kg}$ per day ( $3 \%$ of the body weight) were considered for the above-mentioned livestock categories $[2,55,56]$.

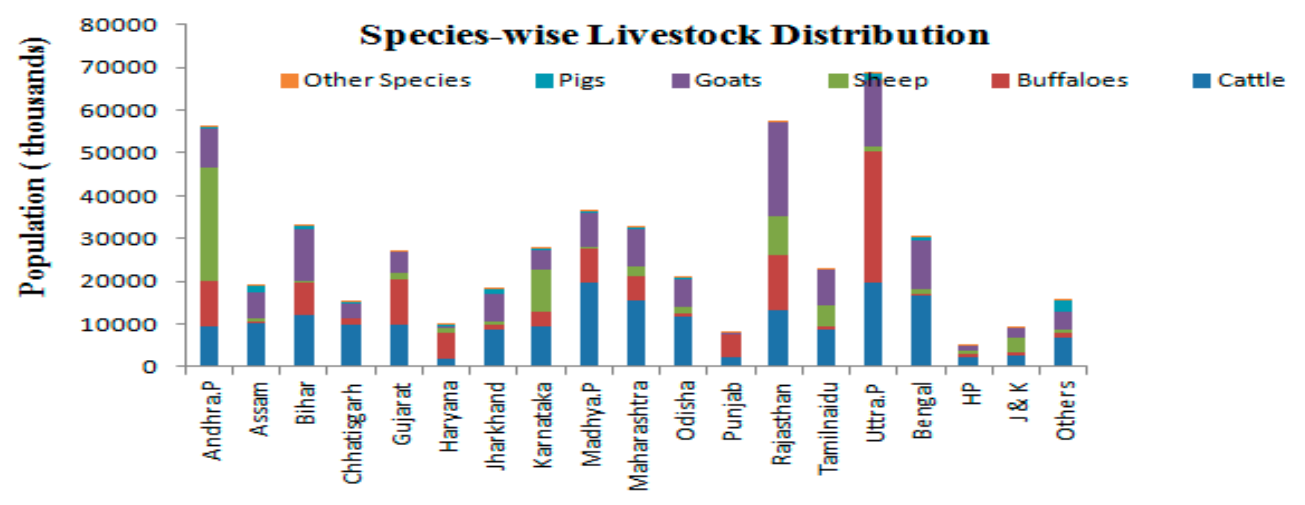

Figure 3. Species-wise livestock distribution in Indian provinces.

\subsection{Determination of the Potential of Biogas and Power Generation}

Cumulative biogas generated from livestock waste depends on many key factors: The type of animal and its breed, typical body weight, type of feed intake, and typical content of total solids excreted in dung waste [53]. However, uniform means of techniques for collection of the dung need to be standardized in order to meet the requirements for generation of ideal quantities of biogas per unit $[53,55,57]$. Hence only from a standardized cumulative biogas volume can the availability coefficient factor can be calculated and considered for determination of the expected and likely biogas yield, as per Equation (1):

$$
\mathrm{TPB}=\mathrm{M} \times \mathrm{TS} \times \mathrm{AC} \times \mathrm{EBTS},
$$

where TPB is the value of 'theoretical potential of biogas' ( $\mathrm{m}^{3}$ per year), $\mathrm{M}$ indicates the cumulative amount of procurable/collectable dung for specific province per year, measured in kilograms, TS denotes percentage of total solids with respect to the gross mass of animal dung, AC denotes the availability coefficient and EBTS is the biogas quantity generated per kilogram of TS $\left(\mathrm{m}^{3}\right.$ per $\mathrm{kg}$ TS). In this study, TS value was assumed to be $25 \%$ from large animal generated waste. As far as small animal waste is concerned, TS was assumed at $29 \%$ for pigs and poultry birds each, with the EBTS value calculated as 0.6 and $0.4,0.8 \mathrm{~m}^{3}$ per $\mathrm{kg}$ TS, respectively. The availability coefficient was assumed as $70 \%$ for large dairy animals, $20 \%$ for small ruminants, and $60 \%$ each in case of waste generated from commercial piggery and poultry industries [55]. It is quite evident that the methane content of biogas depends upon the type of dung used in the anaerobic digestion. Many studies indicate that, during the $\mathrm{AD}$ of cow-dung, average biogas recovered constitutes 50\%-70\% methane. Methane generated from small animals' dung is lesser at $40 \%$ to $50 \%$ [18,19,48,58]. Methane content recoverable from poultry and swine dung on average ranges between of $50 \%-70 \%$ and $60 \%$ [55,56]. In present study, $60 \%$ and $45 \%$ methane content was considered as likely to be generated from large animals, pigs, poultry, and small animals, respectively, as per expected Indian norms. While calculating heating value, heat conversion was calculated as $90 \%$ of total harvested methane, which was denoted as heat 
conversion efficiency in the boiler, assuming that $36 \mathrm{MJ}$ per $\mathrm{m}^{3}$ of methane is the calorific value [56]. For calculation of potential electricity generation from biogas, the following Equation (2) was utilized:

$$
\mathrm{e}_{\text {biogas }}=\mathrm{E}_{\text {biogas }} \times \eta
$$

here $\mathrm{e}_{\text {biogas }}$ is the quantity of electricity generated ( $\mathrm{kWh}$ per year), $\mathrm{E}_{\text {biogas }}$ is the yet to be converted raw energy in the biogas ( $k W h$ per year) and the $\eta$ is the overall conversion efficiency of the biogas to electricity. $\eta$ is variable and largely depends on power plant technology utilized. The $\eta$ value is considered between $35 \%-42 \%$ in large turbine-system-operated power plants and $25 \%$ in small generators. In the current study, the $\eta$ value was assumed as 30\% [58]. By using the following Equation (3), the quantity of $\mathrm{E}_{\text {biogas }}$ is calculated

$$
\mathrm{E}_{\text {biogas }}=\text { Energy content biogas } \times \mathrm{m}_{\text {biogas }},
$$

here, energy content biogas denotes biogas in terms of calorific value of $\left(\mathrm{kWh}\right.$ per $\left.\mathrm{m}^{3}\right)$ and $\mathrm{m}_{\text {biogas }}$ indicates annual quantity of biogas produced $\left(\mathrm{m}^{3}\right.$ per year). Energy content biogas is assumed to be $6 \mathrm{kWh}$ per $\mathrm{m}^{3}$ by considering $21.5 \mathrm{MJ}$ per $\mathrm{m}^{3}$ biogas as the calorific value [58]. For the present study, many factors like national policy, administrative technical guidelines, and financial barriers were not taken into account which can affect future implications of the usefulness of this technique. The key objective of this detailed assessment is to determine the electrical potential likely to be generated by converting dung into biogas. The following section outlines and analyzes some of the essential and pertinent parameters for harnessing this prospective inexhaustible source of energy.

\section{Data Reporting and Results}

\subsection{Potential Quantifiable Sources of Livestock Dung}

As per the latest 19th livestock census, prominent provinces with huge generation of livestock and poultry-based dung are listed in Table 2. From the figures, it is evident that annual generation of dung stands at around 2600 million tons (MT), which is stupendous in terms of amount generated, making it a vital untapped energy source. The largest proportion ( $95 \%$ ) is generated by large dairy animals and the remaining $5 \%$ by small animals including sheep, goats, pigs, and poultry. Prominent among the regional provinces contributing to maximal generation include Uttar Pradesh, Rajasthan, Madhya Pradesh, Andhra Pradesh, Maharashtra, Gujarat, Bihar, and Bengal, of which the dung generation ranges between 149.5 MT to 423.7 MT per annum in an ascending order (Considering a minimum of 150 MT per annum as criterion for grouping the provinces on the basis of dung yield). In terms of percentage, the extent of dung generation has been calculated as 16.74\% in Uttar Pradesh, 9.26\% in Madhya Pradesh, 8.78\% in Rajasthan, and 7\% each in Maharashtra, Gujarat, Bihar, and Andhra Pradesh. If small animal dung generation is considered, Andhra Pradesh emerges as the front-runner with $18 \%$ and $23 \%$ annual yield from small animals and poultry respectively. Assam occupies the exclusive status of being the state with the highest generation of pig dung which stands at $1.5 \mathrm{MT}$ (15\%) per annum.

Table 2. Potential quantifiable sources of livestock dung.

\begin{tabular}{cccccc}
\hline $\begin{array}{c}\text { Provinces/Union } \\
\text { Territories }\end{array}$ & $\begin{array}{c}\text { Large Animal } \\
\text { Dung (MT) }\end{array}$ & $\begin{array}{c}\text { Small Animal } \\
\text { Dung (MT) }\end{array}$ & $\begin{array}{c}\text { Pigs Dung } \\
\text { (MT) }\end{array}$ & $\begin{array}{c}\text { Poultry } \\
\text { Dung (MT) }\end{array}$ & $\begin{array}{c}\text { Total Dung } \\
\text { (MT) }\end{array}$ \\
\hline Andhra P & 166 & 21 & 0.4 & 2.7 & 190.1 \\
Assam & 88 & 4 & 1.5 & 0.5 & 94 \\
Bihar & 163 & 7 & 0.6 & 0.2 & 170.8 \\
Chhattisgarh & 92 & 2 & 0.4 & 0.3 & 94.7 \\
Gujurat & 167 & 4 & 0 & 0.2 & 171.2 \\
Haryana & 65 & 1 & 0.2 & 0.7 & 66.9 \\
Jarkhand & 81 & 4 & 0.9 & 0.2 & 86.1 \\
\hline
\end{tabular}


Table 2. Cont.

\begin{tabular}{cccccc}
\hline $\begin{array}{c}\text { Provinces/Union } \\
\text { Territories }\end{array}$ & $\begin{array}{c}\text { Large Animal } \\
\text { Dung (MT) }\end{array}$ & $\begin{array}{c}\text { Small Animal } \\
\text { Dung (MT) }\end{array}$ & $\begin{array}{c}\text { Pigs Dung } \\
\text { (MT) }\end{array}$ & $\begin{array}{c}\text { Poultry } \\
\text { Dung (MT) }\end{array}$ & $\begin{array}{c}\text { Total Dung } \\
\text { (MT) }\end{array}$ \\
\hline Karnataka & 107 & 8 & 0.3 & 0.9 & 116.2 \\
Madhya P & 228 & 5 & 0.2 & 0.2 & 233.4 \\
Maharashtra & 173 & 6 & 0.3 & 1.2 & 180.5 \\
Odisha & 101 & 5 & 0.3 & 0.3 & 106.6 \\
Punjab & 62 & 0.4 & 0 & 0.3 & 62.7 \\
Rajasthan & 216 & 18 & 0.3 & 0.1 & 234.4 \\
Tamil N & 79 & 7.6 & 0.2 & 1.9 & 88.7 \\
Uttra P & 412 & 10 & 1.4 & 0.3 & 423.7 \\
W. Bengal & 141 & 7 & 0.6 & 0.9 & 149.5 \\
HP & 24 & 1 & 0 & 0.1 & 25.1 \\
J \& K & 29 & 3 & 0 & 0.2 & 32.2 \\
Others & 66 & 3 & 2.5 & 0.7 & 72.2 \\
Total & 2460 & 117 & 10.1 & 11.9 & 2599 \\
\hline
\end{tabular}

\subsection{Potential for Biogas Production}

Livestock and poultry dung has already been identified as a potential raw material for biogas production and considered as a vital aspect in the sustainable development of developing countries in South Asia. The tentative theorized estimate of this untapped source for biogas production is shown in Table 3. Total potential biogas production from all dung sources was calculated in terms of annual yield measured in million $\mathrm{m}^{3}$ per year.

Table 3. Potential for biogas generation (TPB) in provinces.

\begin{tabular}{|c|c|c|c|c|c|}
\hline $\begin{array}{l}\text { Provinces/Union } \\
\text { Territories }\end{array}$ & $\begin{array}{l}\text { Large Animal } \\
\text { Biogas } \\
\left(\text { Million } \mathrm{m}^{3}\right)\end{array}$ & $\begin{array}{l}\text { Small Animal } \\
\text { Biogas } \\
\left(\text { Million } \mathrm{m}^{3}\right)\end{array}$ & $\begin{array}{l}\text { Pigs Biogas } \\
\left(\text { Million } \mathbf{m}^{3} \text { ) }\right.\end{array}$ & $\begin{array}{l}\text { Poultry Biogas } \\
\left(\text { Million } \mathrm{m}^{3} \text { ) }\right.\end{array}$ & $\begin{array}{l}\text { Total Biogas } \\
\left(\text { Million } \mathrm{m}^{3} \text { ) }\right.\end{array}$ \\
\hline Andhra P & 17,430 & 420 & 55.68 & 375.84 & $18,281.5$ \\
\hline Assam & 9240 & 80 & 208.8 & 69.6 & 9598.4 \\
\hline Bihar & 17,115 & 140 & 83.52 & 27.84 & $17,366.3$ \\
\hline Chhattisgarh & 9660 & 40 & 55.68 & 41.76 & 9797.4 \\
\hline Gujurat & 17,535 & 80 & 0 & 27.84 & 6970.28 \\
\hline Haryana & 6825 & 20 & 27.84 & 97.44 & 66.9 \\
\hline Jarkhand & 8505 & 80 & 125.28 & 27.84 & 8738.1 \\
\hline Karnataka & 11,235 & 160 & 41.76 & 125.28 & 11,562 \\
\hline Madhya P & 23,940 & 100 & 27.84 & 27.84 & $24,095.6$ \\
\hline Maharashtra & 18,165 & 120 & 41.76 & 167.04 & $18,493.8$ \\
\hline Odisha & 10,605 & 100 & 41.76 & 41.76 & $10,788.5$ \\
\hline Punjab & 6510 & 8 & 0 & 41.76 & 6559.7 \\
\hline Rajasthan & 22,680 & 360 & 41.76 & 13.92 & $23,095.6$ \\
\hline Tamil N & 8295 & 152 & 27.84 & 264.48 & 8739.32 \\
\hline Uttra P & 43,260 & 200 & 194.88 & 41.76 & $43,696.6$ \\
\hline W. Bengal & 14,805 & 140 & 83.52 & 125.28 & $15,153.8$ \\
\hline $\mathrm{HP}$ & 2520 & 20 & 0 & 13.92 & 2553.9 \\
\hline $\mathrm{J} \& \mathrm{~K}$ & 3045 & 60 & 0 & 27.84 & 3132.8 \\
\hline Others & 6930 & 60 & 348 & 97.44 & 7435.44 \\
\hline Total & 258,300 & 2340 & 1405.9 & 1656.48 & $263,702.4$ \\
\hline
\end{tabular}

Considering figures of expected yield of biogas per annum, Uttar Pradesh at 43,696 million $\mathrm{m}^{3}$ leads the pack, followed by Madhya Pradesh at 24,095 million $\mathrm{m}^{3}$, Rajasthan at 23,095 million $\mathrm{m}^{3}$, Andhra Pradesh at 18,281 million $\mathrm{m}^{3}$, Maharashtra at 18,493 million $\mathrm{m}^{3}$, Gujarat at 17,642 million $\mathrm{m}^{3}$, Bihar at 17,366 million $\mathrm{m}^{3}$, and Bengal at 15,153 million $\mathrm{m}^{3}$. Of this, $98 \%$ of total dung utilizable for biogas production is obtainable from large (dairy) animals and the remaining $2 \%$ from smaller domesticated animals as well as poultry. Andhra Pradesh leads other provinces with respect to the maximal exploitable biomass being generated from small animal farms and the poultry industry, with a total estimated yield of 795 million tons of biogas per annum. In terms of dung obtainable from pig-rearing provinces, the expected biogas yield stands at 1400 million $\mathrm{m}^{3}$ per annum. Assam 
leads with an annual potential of 208 million $\mathrm{m}^{3}(15 \%)$, followed by Uttar Pradesh at 195 million $\mathrm{m}^{3}$ $(14 \%)$. Biogas potential from animal dung has already been calculated and exploited with annual figures from some of the prominent countries of the world in this arena showing at 481.7 million $\mathrm{m}^{3}$ for Sweden, 550.7 million $\mathrm{m}^{3}$ for Denmark, 461.9 million $\mathrm{m}^{3}$ for Finland, 8599.8 million $\mathrm{m}^{3}$ for Iran, 1477.4 million $\mathrm{m}^{3}$ for Turkey, and 4589.5 million $\mathrm{m}^{3}$ for Malaysia $[55,56]$.

\subsection{Estimates of Methane Yield and Corresponding Heating Value Obtainable from Biomass}

The methane content of biogas was calculated by assuming standard content of methane produced from the variety of dung sources under consideration. Total estimate of methane yield from all sources of animal dung for the country was calculated as 157,870 million $\mathrm{m}^{3}$ per annum. Further calculations suggest that this methane gas if utilized as an energy source can yield heat energy of about 5,146,576 million MJ per annum.

\subsection{Calculation of Electrical Potential}

Detailed calculations were carried out to estimate the exploitation of methane from biogas generated from animal dung as fuel for generating electricity. Table 4 shows the calculated results compiled on the basis of the resource exploited, and the potential in each state. From the illustration and Figure 4, it is evident that highest potential, in terms of recoverable electrical energy in Terawatt hour (TWh) on an annual basis, exists in Uttar Pradesh at 16.6\% (79 TWh), followed by Madhya Pradesh 9.15\% (43.5 TWh), Rajasthan 8.75\% (41.6 TWh), Maharashtra 7\% (33.4 TWh), Andhra Pradesh 6.9\% (32.9 TWh), Gujarat 6.7\%( 31.9 TWh), Bihar 6.6\%(33.1 TWh), and Bengal 5.6\% (27.3 TWh). In India, total dung available stands at 2600 million tons per annum which has the potential to generate 263,702 million $\mathrm{m}^{3}$ of biogas each year. As shown in calculations above, the methane yield from biogas stands at 157,870 million $\mathrm{m}^{3}$ per annum, which has heating value of 5,146,576 million MJ that possesses the capacity to generate an additional 477 TWh of electrical energy per annum, which by all means is a significant figure. A similar study carried out in the United Provinces reported that animal dung generated across all provinces in the continent has a potential of 928 trillion BTU in terms of raw energy which can be utilized to generate heat and electricity, meeting approximately one percent of energy demand [58]. Previous studies carried out in India claim a biogas potential of 16,030 million $\mathrm{m}^{3}$ from collectable dung considering only dairy animal dung generated in the country. According to this study, as per the figures in Year 1997, dung collected from cows and buffaloes stand at 458 million tons per annum, with an energy potential of 336 PJ [52]. Small ruminants, pigs, and poultry were not considered in this potential estimate [52].

Table 4. Estimated electrical energy potential of Indian provinces.

\begin{tabular}{cccccc}
\hline $\begin{array}{c}\text { Provinces/Union } \\
\text { Territories }\end{array}$ & $\begin{array}{c}\text { Large Animal } \\
\text { Potential } \\
\text { (TWh) }\end{array}$ & $\begin{array}{c}\text { Small Animal } \\
\text { Potential } \\
\text { (TWh) }\end{array}$ & $\begin{array}{c}\text { Pigs Potential } \\
\text { (TWh) }\end{array}$ & $\begin{array}{c}\text { Poultry } \\
\text { Potential } \\
\text { (TWh) }\end{array}$ & $\begin{array}{c}\text { Total Eletrical } \\
\text { Potential } \\
\text { (TWh) }\end{array}$ \\
\hline Andhra P & 31.57 & 0.57 & 0.1 & 0.68 & 32.92 \\
Assam & 16.73 & 0.11 & 0.38 & 0.13 & 17.35 \\
Bihar & 31 & 0.19 & 0.15 & 0.05 & 31.4 \\
Chhattisgarh & 17.5 & 0.054 & 0.10 & 0.076 & 17.8 \\
Gujurat & 31.76 & 0.11 & 0 & 0.050 & 31.92 \\
Haryana & 12.36 & 0.027 & 0.050 & 0.18 & 12.61 \\
Jarkhand & 15.4 & 0.11 & 0.23 & 0.050 & 15.79 \\
Karnataka & 20.35 & 0.22 & 076 & 0.23 & 20.87 \\
Madhya P & 43.36 & 0.14 & 0.050 & 0.050 & 43.6 \\
Maharashtra & 32.9 & 0.16 & 0.076 & 0.3 & 34.34 \\
Odisha & 19.2 & 0.14 & 0.076 & 0.076 & 19.5 \\
Punjab & 11.8 & 0.011 & 0 & 0.076 & 11.88 \\
Rajasthan & 41.08 & 0.49 & 0.075 & 0.025 & 41.67 \\
Tamil N & 15.02 & 0.20 & 0.05 & 0.48 & 15.76 \\
Uttra P & 78.35 & 0.27 & 0.35 & 0.076 & 79.05 \\
Bengal & 26.81 & 0.19 & 0.15 & 0.23 & 27.38 \\
HP & 4.56 & 0.027 & 0 & 0.025 & 4.62 \\
J \& K & 5.51 & 0.082 & 0 & 0.050 & 5.65 \\
Others & 12.55 & 0.082 & 0.63 & 0.18 & 13.44 \\
Total & 467.81 & 3.18 & 2.55 & 3 & 476.53 \\
\hline
\end{tabular}




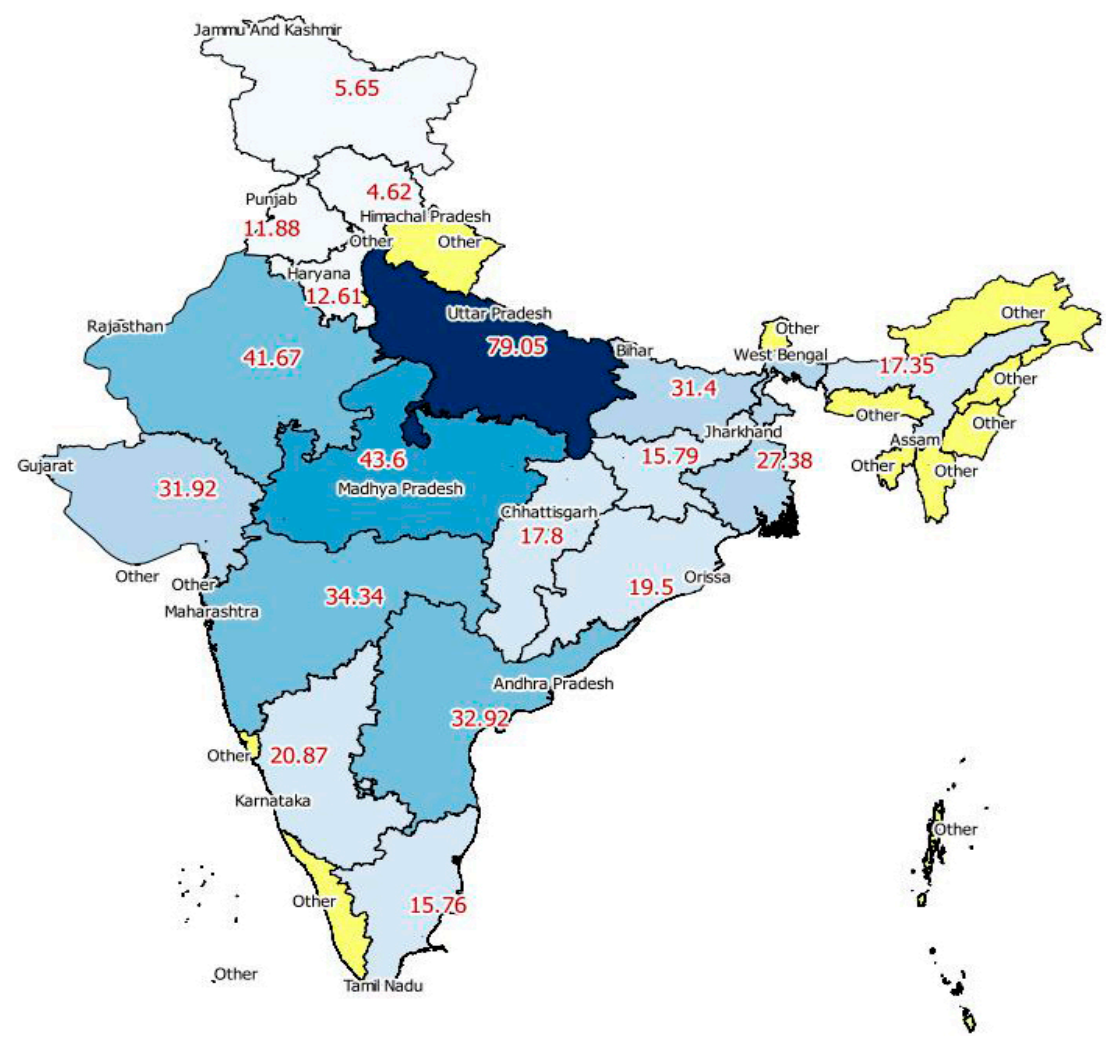

Figure 4. Potential of electrical energy generation (TWh per year) in different provinces of India.

The observations in this study with regard to the potential for energy generation are divergent from our calculations primarily because of variations inherent in the timing of the study, growth in animal population, higher recoverable dung mass per animal at present, availability of better techniques of energy extraction due to improved methods of extraction as per latest available technology, and consideration of all species of domesticated animals as generators of biomass in our study. The present annual electric energy demand in India has been calculated at 98,734 MU units. By our calculations, 477 TWh of electrical energy generation is possible from the identified biogas resources in our study, even if the lowest energy conversion efficiency at $25 \%$ is considered. If higher energy conversion efficiency is achievable by some means, an even greater amount of electricity can be generated. Our study suggests that livestock and poultry-based dung biomass utilization for electricity production can contribute to decreasing electric power generation costs in a consistent and sustainable manner, if exploited judiciously. This can contribute to reducing the expenditure on conventional fuels presently being employed to generate electricity in India. Coal, a non-renewable and heavily-mined raw material used for electricity generation at present is a major financial burden on the exchequer, in addition to its implications on environmental pollution. Biomass-based sustainable green energy production, by utilizing the huge biomass generated as animal waste can go a long way to reduce this burden.

\section{Conclusions}

India is largely an agrarian society with the majority of the population thriving in rural, environs enriched with natural resources. Livestock and poultry dung waste is a vital biomass resource that is largely wasted. Current utilization of this precious biomass involves conversion of dung into biogas by effective utilization of organic wastes through recycling operations and sometimes conversion to electrical energy in modern large-scale dairies. A robust analysis of livestock and poultry biomass generated in India and its potential as a renewable energy source has been presented. It can be safely 
expected that the vast biomass generated as livestock dung in India at 2600 million tons per annum has huge potential if exploited as an energy source. Our calculations suggest that it may be possible to generate 477 TWh of electrical energy per annum if the current potential of livestock dung to generate 263,702 million $\mathrm{m}^{3}$ of biogas is exploited. Over the years, anaerobic digestion technology has improved substantially to maximize the production of harvestable biogas from livestock dung. This means that modern AD technology may effectively contribute to higher yields of biogas, particularly methane, which can serve as a green and renewable source of energy. However, there exist plenty of bottlenecks in initiating and actually making use of such technologies. Some of the identifiable bottlenecks include economic constraints in building the infrastructure, logistic issues, outdated and inefficient mechanisms of waste disposal, collection and management, and a general lack of acceptability to new ideas in favor of time-tested traditional methods of waste disposal. Despite constraints, even a fraction of this dung-based sustainable energy source, if utilized judiciously, can revolutionize rural lifestyles and open the door for establishing modern industries requiring electricity in the rural sector. Moreover, as traditional mechanisms of waste disposal are already operational, this new venture will hardly make a dent in the present rural lifestyle, as the technology needs to be made operational in a step-wise manner. Potential ventures in this arena need to be introduced in regions with heavy dairy presence as a means of livelihood. Pilot projects of this nature are already in operation and need to be strengthened to harness this green and sustainable source of energy.

Acknowledgments: The work is based on the doctorate thesis of the first author, who wants to affectionately express gratitude to her mentors. We deeply indebted to Rupinder Singh Kanwar and Charanjeet Sarangal for their invaluable contribution in english editing and livestock data handling. We are very grateful to I.K. Gujral Punjab Technical University for academic and technical support.

Author Contributions: Gagandeep Kaur contributed comprehensively to the preparation of manuscript. Yadwinder Singh Brar gave the technical advice and improved the structure of manuscript and, D. P. Kothari confer the scientific expert guidance for this study. All the authors have approved the submission of manuscript.

Conflicts of Interest: No potential conflict of interest reported by authors.

\section{Abbreviations}

\section{Units Used}

MU Million Units

BU Billion Units

MW Mega Watts

MJ Mega Joules

MT Million Tones

kWh Kilowatt hours

TWh Terawatt hours

PJ Peta Joules

\section{References}

1. IPCC. Climate Change 2014 Synthesis Report Summary for Policymaker's Summary. Available online: https://www.ipcc.ch/pdf/assessment-report/ar5/syr/SYR_AR5_FINAL_full_wcover.pdf (accessed on 28 March 2016).

2. Scheftelowitz, M.; Thran, D. Unlocking the energy potential of dung-An assessment of the biogas production potential at the farm level in Germany. Agriculture 2016, 6, 20. [CrossRef]

3. Hosseini, S.E.; Wahid, M.A.; Aghili, N. The scenario of greenhouse gases reduction in Malaysia. Renew. Sustain. Energy Rev. 2013, 28, 400-409. [CrossRef]

4. Hosseini, S.E.; Wahid, M.A. Development of biogas combustion in combined heat and power generation. Renew. Sustain. Energy Rev. 2014, 40, 868-875. [CrossRef]

5. Exxonmobil 2017 the Outlook for Energy: A View to 2040. Available online: http:/cdn.exxonmobil.com/ / media/global/files/outlook-for-energy/2017/2017-outlook-for-energy.pdf (accessed on 15 April 2017). 
6. Abdeshahian, P.; Al-Shorgani, N.K.N.; Salih, N.K.M.; Shukor, H.; Kadier, A.; Hamid, A.A.; Kalil, M.S. The production of biohydrogen by a novel strain Clostridium sp. YM1 in dark fermentation process. Int. J. Hydrog. Energy 2014, 39, 12524-12531. [CrossRef]

7. Atlas of Sustainable Development Goals 2017 from World Bank Development Indicators. Available online: http:/ / openknowledge.worldbank.org/handle/10986/26306 (accessed on 28 March 2016).

8. World Development Indicator. Available online: http://wdi.worldbank.org/table/WV.1 (accessed on 28 March 2016).

9. Mukhopadhyay, K. An assessment of biomass gasification based power plant in the sunderbans. Biomass Bioenergy 2004, 27, 253-264. [CrossRef]

10. Sinha, C.S.; Ramana, P.V.; Joshi, V. Rural energy planning in India: Designing effective intervention strategies. Energy Policy 1994, 22, 403-414. [CrossRef]

11. Suresh, C. Biomass resource assessment for power generation: A case study from Haryana state, India. Biomass Bioenergy 2010, 34, 1300-1308.

12. Bhattacharyya, S.C. Energy access problem of the poor in India: Is rural electrification a remedy? Energy Policy 2006, 34, 3387-3397. [CrossRef]

13. Murphy, J.D.; McKeogh, E. Technical, economic and environmental analysis of energy production from municipal solid waste. Renew. Energy 2004, 29, 1043-1057. [CrossRef]

14. Chasnyk, O.; Solowski, G.; Shkarupa, O. Historical technical and economic aspects of biogas development: Case of Poland and Ukraine. Renew. Sustain. Energy Rev. 2015, 52, 227-239. [CrossRef]

15. Sun, Q.; Li, H.; Yan, J.; Liu, L.; Yu, Z.; Yu, X. Selection of appropriate biogas upgrading technology-A review of biogas cleaning, upgrading and utilization. Renew. Sustain. Energy Rev. 2015, 51, 521-532. [CrossRef]

16. Logan, B.E.; Regan, J.M. Microbial challenges and fuel cell applications. Environ. Sci. Technol. 2010, 40, 5172-5180. [CrossRef]

17. Rahimnejad, M.; Adhami, A.; Darvari, S. Microbial fuel cell as new technology for bioelectricity generation: A review. Alex. Eng. J. 2015, 54, 745-756. [CrossRef]

18. Rabaey, K.; Lissens, G.; Siciliano, S.D.; Verstraete, W. A microbial fuel cells capable of converting glucose to electricity at high rate and efficiency. Biotechnol. Lett. 2003, 25, 1531-1535. [CrossRef] [PubMed]

19. Raj, A.; Jhariya, M.K.; Toppo, P. Cow-dung for eco-friendly and sustainable productive farming. Int. J. Sci. Res. 2014, 3, 201-202.

20. Understanding Energy Challenges in India. Available online: http://www.iea.org/publications/ freepublications/publications/publication/india_study_FINAL_WEB.pdf (accessed on 28 March 2017).

21. National Electricity Plan. Volume 1, Generation. Available online: http:/ / climateobserver.org/wp-content/ uploads /2015/01/National-Electricity-Plan.pdf (accessed on 15 February 2017).

22. Energy Statistics 2016. Twenty Third Issue by Central Statistics Office. Available online: http://mospiold. nic.in/Mospi_New/upload/Energy_statistics_2016.pdf (accessed on 26 December 2016).

23. 19th Livestock Census, All India Report. Ministry of Agriculture and Farmer welfare, Department of Animal Husbandry, Dairying \& Fisheries, Government of India. Available online: http://www. indiaenvironmentportal.org.in/content/399839/19th-livestock-census-2012-all-india-report/ (accessed on 15 September 2016).

24. Kumar, A.A. A study on renewable resources in India. In Proceedings of the IEEE International Conference on Environmental Engineering \& Application (ICEEA), Singapore, 10-12 September 2010; pp. 49-53.

25. Saha, S.; Biswas, S.; Pal, S. Survey analysis scope and applications of biomass energy in India. In Proceedings of the 2014 1st International Conference on Non Conventional Energy (ICONCE 2014), Kalyani, West Bengal, India, 16-17 January 2014; pp. 136-141.

26. Varshney, R.; Bhagoria, J.L.; Mehta, C.R. Small scale biomass gasification technology in India-An overview. J. Eng. Sci. Manag. Educ. 2010, 3, 33-40.

27. Energy for All: Financial Access for the Poor. Available online: http://www.iea.org/media/weowebsite/ energydevelopment/presentation_oslo_oct11.pdf (accessed on 14 September 2015).

28. Balachandra, P. Dynamics of rural energy access in India: An assessment. Energy 2012, 36, 5556-5567. [CrossRef]

29. Power Sector at a Glance all India. Available online: http:/powermin.nic.in/en/content/power-sectorglance-all-India (accessed on 14 April 2017). 
30. Report on Power Sector 2017. Available online: http:/ / cea.nic.in/reports/monthly/executivesummary / 2017/exe_summary-01.pdf (accessed on 3 April 2017).

31. Pachauri, S.; Jiang, L. The household energy transition in India and China. Energy Policy 2008, 36, 4022-4035. [CrossRef]

32. Kumar, A.; Kumar, N.; Baredar, P.; Shukla, A. A review on biomass energy resources, potential, conversion and policy in India. Renew. Sustain. Energy Rev. 2015, 45, 530-539. [CrossRef]

33. Biomass Knowledge Portal. Available online: http:/ / biomasspower.gov.in/ (accessed on 7 May 2017).

34. DADF 2016-17. Annual Report. Ministry of Agriculture and Farmer welfare, Department of Animal Husbandry, Dairying \& Fisheries, Government of India. Available online: http:/ /dahd.nic.in/sites/default/ files/Annual\%20Report\%202016-17.pdf (accessed on 17 April 2017).

35. Review of Emission Factors and Methodologies to Estimate Ammonia Emissions from Animal Waste Handling. Available online: https:/cfpub.epa.gov/si/si_public_record_Report.cfm?dirEntryID=55098 (accessed on 28 March 2016).

36. The US Inventory of Greenhouse Gas emission and Sinks: Fast Facts. Available online: https://www.epa. gov/ghgemissions / fast-facts-inventory-us-greenhouse-gas-emissions-and-sinks-1990-2014 (accessed on 17 January 2016).

37. Martinez, J.; Dabert, P.; Barrington, S.; Burton, C. Livestock waste treatment systems for environment quality, food safety and sustainability. Bioresour. Technol. 2009, 100, 5527-5536. [CrossRef] [PubMed]

38. Nasir, I.M.; Ghazi, T.I.M.; Omar, R.; Idris, A. Anaerobic digestion of cows dung: Influence of inoculums concentration. Int. J. Eng. Technol. 2013, 10, 22-26.

39. Fraenkel, P.L. Biomass and Coal (the Non-Petroleum Fuel). In Water lifting Device, FAO Irrigation and Drainage paper 43; Food and Agriculture Organization of the United Nations: Rome, Italy, 1986; pp. 286-306.

40. Sunil, B.; Mathews, E.B. Management of livestock waste. J. Indian Vet. Assoc. 2015, 13, 13-15.

41. Resource Assessment for Livestock and Agro-Industrial Wastes-India. Available online: https://www. globalmethane.org/documents/ag_india_res_assessment.pdf (accessed on 15 February 2017).

42. Surendra, K.C.; Takar, D.; Andrew, G.; Hashimoto; Khandal, S.K. Biogas sustainable energy source for developing countries: Opportunities and challenges. Renew. Sustain. Energy Rev. 2014, 31, 846-859. [CrossRef]

43. Maithal, S. Biomass Energy Resources Assessment Handbook. Available online: http://apctt.org/recap/ sites/all/themes/recap/pdf/Biomass.pdf (accessed on 4 April 2016).

44. Fact Sheet "Biomass-An Important Renewable Energy Sources". Available online: http://www.wmaa.asn. $\mathrm{au} /$ lib/pdf/07_publications/1306_biogas_factsheet.pdf (accessed on 6 May 2017).

45. Gupta, K.K.; Aneja, K.R.; Rana, D. Current status of cow as a bioresource for sustainable development. Bioresour. Bioprocess 2016, 3. [CrossRef]

46. Rao, P.V.; Baral, S.S.; Day, R.; Mutnuri, S. Biogas generation potential by anerobic digestion for sustainable energy development in India. Renew. Sustain. Energy Rev. 2010, 14, 2086-2094. [CrossRef]

47. Buragohain, B.; Mahanta, P.; Moholkar, V.S. Biomass gasification for decentralized power generation: Indian perspective. Renew. Sustain. Energy Rev. 2010, 14, 73-92. [CrossRef]

48. Lovely, D. Microbial fuel cells: Novel microbial physiologies and engineering approaches. Curr. Opin. Biotechnol. 2006, 17, 327-332. [CrossRef] [PubMed]

49. Franks, A.E.; Nevin, K.P. Microbial fuel cells: A current review. Energies 2010, 3, 899-919. [CrossRef]

50. Tharali, A.D.; Sain, N.; Osborme, W. Microbial fuel cells in bioelectricity production. Front. Life Sci. 2016, 9 , 252-266. [CrossRef]

51. Lovely, D.R.; Juice, B. Harvesting electricity with microorganism. Nat. Rev. Microbiol. 2006, 4, 497-508. [CrossRef] [PubMed]

52. Ravindranatha, N.H.; Somashekara, H.I.; Nagarahjaa, M.S.; Sudhaa, P.; Sangeethaa, G.; Bhattacharya, S.C.; Salam, P.A. Assessment of sustainable non plantation biomass resource potential for energy in India. Biomass Bioenergy 2005, 29, 178-190. [CrossRef]

53. Avcioglu, A.O.; Turker, U. Status and potential of biogas energy from animal wastes in Turkey. Renew. Sustain. Energy Rev. 2012, 16, 1557-1561. [CrossRef]

54. Kaygusuz, K. Renewable and sustainable energy use in Turkey: A review. Renew. Sustain. Energy Rev. 2002, 6, 339-366. [CrossRef] 
55. Afazeli, H.; Jafari, A.; Rafiee, S.; Nosrati, M. An investigation of biogas production potential from livestock and slaughter house wastes. Renew. Sustain. Energy Rev. 2014, 34, 380-386. [CrossRef]

56. Abdeshhahian, P.; Lee, J.S.; Ho, W.S.; Hashim, H.; Lee, C.T. Potential of biogas production from farm animal waste in Malaysia. Renew. Sustain. Energy Rev. 2016, 60, 714-723. [CrossRef]

57. Deublein, D.; Steinhauser, A. Biogas from Waste and Renewable Resources: An Introduction; Wiley-VCH-Verl: Weinheim, Germany, 2011.

58. Cu'ellar, A.D.; Webber, M.E. Cow power: The energy and emissions benefits of converting dung to biogas. Environ. Res. Lett. 2008, 3. [CrossRef]

(C) 2017 by the authors. Licensee MDPI, Basel, Switzerland. This article is an open access article distributed under the terms and conditions of the Creative Commons Attribution (CC BY) license (http://creativecommons.org/licenses/by/4.0/). 